\title{
Difficulties in Transition among Livelihoods under Agricultural Land Conversion for Industrialization: Perspective of Human Development
}

\author{
Duong Duc Dai \\ Le Thi Ngan \\ Nguyen Thi Dien \\ Faculty of Political and Social Science, Hanoi University of Agriculture, Vietnam
}

Doi:10.5901/mjss.2013.v4n10p259

\begin{abstract}
Increasing industrialization in Vietnam has transformed numerous fields of farmers to industrial zones, especially in the Red River Delta in Vietnam. This process forces farmers to change significantly their livelihoods. Affected same changes, farmers have to start new livelihoods. However, in many industrializing regions, inequality and social differentiation are increasing higher than before among farmers practicing new livelihoods. This implies that new livelihoods of partly farmer groups are not as good as those of others. Such farmer groups have faced difficulties preventing them to have better livelihoods, and creating hidden social stratification. From perspective of human development as capabilities expansion, this research identifies difficulties and farmers' capabilities during the process of starting new livelihood. As preliminary results, there are farmer groups having limited choices for new good livelihoods. Main difficulties in transition livelihoods are lack of financial resources, new working skills, market information, market linkages, and constraint of age. Such problems create deprivation of capability or freedom in starting new good livelihood. Of methodology, the research examines changes in livelihoods of farmers who are affected from agricultural land conversion for industrialized zones in Red River Delta, Vietnam. In-depth interview and group discussion are taken to understand transition in livelihoods, and farmers 'capabilities in starting new livelihoods. This research contributes to human development discourse from aspect of livelihoods. Also, identifying difficulties is useful for explaining inequality and social differentiation under industrialization. The research is helpful for policy makers and state staffs who design and implement policies of agriculture and industrialization.
\end{abstract}

\section{Introduction}

Increasing industrialization in Vietnam since 1990s put great changes on farmers. Numerous fields had to be transformed to industrial zones, especially in the Red River Delta in Vietnam. Without agricultural land, farmers are changing significantly to new livelihoods. However, in many industrializing regions, inequality and social differentiation are increasing higher than before among farmers practicing new livelihoods. The transition of livelihoods after agricultural land conversion seems to be painful for farmers. They have faced a range of difficulties preventing them to have better livelihoods, and creating hidden social differentiation and inequality. It is a deep change of identities from farmers to workers, sellers, vendors, bosses, and so on. Correspondingly, transition to new livelihoods came with changes of farmer's capabilities in different directions depending how good new livelihoods are. Considering human development as capabilities expansion, it is certainly that industrialization influent to human development through the mechanism of livelihoods and capabilities. Hence, agricultural land conversion challenged human development of farmers. It is necessary to unlock how capabilities of farmers have changed under the transitions between livelihoods, and what are main difficulties within the transition? Of methodology, the research examines changes in livelihoods of farmers who are affected from agricultural land conversion for industrialized zones in Red River Delta, Vietnam. In-depth interview and group discussion are taken to understand transition in livelihoods, and farmers 'capabilities in starting new livelihoods. This research contributes to human development discourse from aspect of livelihoods. Also, identifying difficulties is useful for explaining inequality and social differentiation under industrialization. The research is helpful for policy makers and state staffs who design and implement policies of agriculture and industrialization, especially policies of land. 


\section{Literature Review and Analytical Framework}

\subsection{Livelihoods in transition}

\subsubsection{Transition of livelihoods}

Transition of livelihoods is researched in specific case studies, mainly in cases that moving citizens for massive construction or industrial zones. In those cases, people have to stop their livelihood to begin new livelihoods in new contexts.

Jeffrey Bury examined how transnational gold mining operation creates local changes in Cajamarca, Peru (Bury, 2004). The author identified four types of capital forming changes in livelihoods: Produced capital (savings, convertible liquid assets, earned income, pensions, transfers from the state, other remittances, infrastructural components as buildings, transportation, electrical services); Human capital (skills, education, knowledge, ability to labour, health); Natural capital (non-renewable resources - minerals, forests, soils - and renewable ones - ecosystem services, nutrient cycling; Social capital (stocks of mutual trust or beneficial connections for people). Jeffrey Bury found that gold mining operation had reduced natural capital and social, meanwhile, increase produced capital and human capital. Under impacts of the external factors, household's livelihoods transited uncertainly and shifted opportunities for resources access among different groups in the community. The research raised issue of evaluation to decrease and increase of different resources at the same time.

In China, the famous case studies of the Three Gorges Dam had been analysed its great impact on livelihoods of approximately 1.3 million people living inside the super dam construction (Trouw, 2007). The core part of Three Gorges Dam project is the resettlement program. All households living in the area inundated by the Three Gorges Dam had to move to new place. Hence, their main resources as land, savings, their labor, social ties, and communal resources became less during the resettlement process. Such Chinese households borrowed a lot to build new housing and other things. Their adaptation reflected many difficulties during the resettlement process. Research group of Brooke Wilmsen found that households" incomes fell after resettlement especially those ones had more lost land. Furthermore, households become more vulnerable to further external shocks than they were before the resettlement (Wilmsen et al., 2011).

Similarly in Vietnam, hydropower development in all regions created serious problems of livelihoods for thousands people living inside large dams as Son La Dam, Ban Ve Dam, Tuyen Quang Dam (Anh, 2007). Research of Bui Thi Minh Hang in 2011 and 2013 also indicates that affected households had to adapt passively to involuntary resettlement by Son La Hydropower Dam. The livelihood adaptation of resettled households was strongly conditioned by a lack of available livelihood assets in the remote mountain location. Meanwhile, main compensation money has been consumed rather than invested in livelihood assets. Hence, livelihood outcomes could worsen if the compensation ends. The author raised the issue of sustainability of livelihoods after resettlement (Bui and Schreinemachers, 2011, Bui et al., 2013). A range of investigation on other hydropower projects in Quang Nam, Hue, Gia Lai, Kon Tum, Phu Yen, Dak Lak, Tuyen Quang, Hoa Binh provinces have shown that new livelihoods of affected people are not better or even equal to previous livelihoods before resettlement programs (Ha et al., 2013, Ha and Tranh, 2011).

Households on those above investigations were forced to move out from their living places, and then their livelihoods were moved simultaneously. They still can continue their livelihoods at resettled places. Those cases are quite different from case study of agricultural land conversion and farmers' livelihoods. In which, after losing almost agricultural land, households had to start a different livelihood. However, above results are still useful for understanding how livelihoods transit from one to another.

\subsubsection{Livelihoods approach}

Concepts of livelihood are different due to the diversity of the ways people make a living. Chambers (1995) defined livelihood as "the means of gaining a living" (Chambers, 1995). Livelihood can be seen as a combination of the resources used and the activities undertaken in order to live.

Livelihoods perspectives have been central to rural development thinking and practice in the past decade (Scoones, 2009). Rural livelihoods become an important aspect for investigation of development regarding to poverty. In 1980s, livelihood perspective had raised attention when Norman Long developed his distinctive actor-oriented approach (Long, 1984). Literature of livelihoods developed essentially with the emergence of sustainable rural livelihoods approach 
by M.S.Swaminathan, Robert Chambers (Swaminathan, 1987, Chambers, 1987, Chambers, 1983). In this approach, a livelihood comprises the capabilities, assets (including both material and social resources) and activities for a means of living. A livelihood is sustainable when it can cope with and recover from stresses and shocks, maintain or enhance its capabilities and assets, while not undermining the natural resource base (Chambers and Conway, 1992).

Livelihoods are built on certain capitals: natural capital, economic/financial capital, human capital, social capital, and physical capital (Ellis, 2000: p8). Hence, individuals and households' livelihoods can be traced back to such five capitals. By contrast, those capitals are enough to explain livelihoods.

Definition of Chambers and Conway lacks an important attribute of livelihoods which is the access that individuals and households have to different types of capital, opportunities, and services. The access allows people to control and use other resources from surrounding people. Access also includes the ability to participate in, and derive benefits from social and public services as education, health services, and so on. Hence Frank Ellis proposed a definition "a livelihoods comprises the assets (natural, physical, financial and social capital), the activities, and the access to these (mediated by institutions and social relations) that together determine the living gained by the individual or household" (Ellis, 2000: p10). This definition is also used throughout this paper.

Capabilities were introduced in Capability Approach by Amartya Sen. The capability approach praises freedom of human beings "by expanding the range of things that a person can be and do, such as to be healthy and well nourished, to be knowledgeable, and to participate in community life", in short, it is freedom to choose what people value (FukudaParr, 2003: 303). Expansion of capabilities is considered as human development. Hence, livelihoods as a set of capabilities contribute essentially to "a people-oriented development". At the same time, capabilities influence and be influenced by livelihoods. In this paper, the author concerns mainly capabilities as dependents of livelihoods.

\subsection{Agricultural land conversion and farmers' livelihoods in Vietnam}

In Vietnam, impact of agricultural land conversion on farmers' livelihoods is significant because they have lost land - the most important material of agricultural production. In the investigation conducted from 2007 to 2011 in Hung Yen province - an industrialized region in the Red river delta, Nguyen Thi Dien categorized farmers' adaptation in three strategies: Agricultural intensification, diversification, and non-farm livelihoods. The research also revealed how different farmers group benefit or suffer losses from agricultural land conversion. Households specialized into non-farm livelihoods that they have comparative advantages: opening restaurants, shops, beauty salons, guesthouses, urban-rural trade. Some active households develop rural manufacturing and family business, for example, waste recycling, footwear making, and leather goods production (Dien, 2011).

Not by land conversion, but rural households in the down stream flooding area in the Mekong Delta also lost their land by flooding. They need to change to other livelihoods. Research group of Vu Van Tuan examined livelihoods of landless rural households in the down stream flooding area in the Mekong Delta. They found that landless household livelihoods had been falling into most difficulty as no financial capital, less education, low working skills, and low social voice. Hence, they had to earn incomes by several other employment rather than agricultural activities. Besides, they were always suffered risks of health problem, debt, and unemployment (Tuan et al., 2008).

Together with industrialization, urbanization influence strongly to livelihoods of rural people because rural areas transform themselves to be urban, and urban areas attract so many farmers for increasing labour demand. The research of Le Canh Dung's group analyses the impact of urbanization on livelihoods strategies of rural people, especially impact on agricultural and employment transition. They found that agricultural livelihoods have declining trend; meanwhile, nonagricultural livelihoods are growing. Besides, employment structure of rural people is varied, in which agricultural labour is decreasing and labour in manufacturing and services is increasing. This research identified two livelihood strategies of local people to response with urbanization: Firstly, developing high technological and sustainable agriculture associating with linkage of marketing channel; Secondly, developing of non-agricultural employment are priority to develop in the near future (Dung et al., 2008).

Such above investigations stress on how livelihoods are changed under determinants as land conversion, natural disaster (flooding), or urbanization. Many researchers mixed difficulties in transition between livelihoods of farmers to characteristics of new contexts created by above determinants. However, it is necessary to distinguish barriers that preventing rural people to have better livelihoods. 


\subsection{Analytical framework}

nalytical framework of this research connects livelihoods and capabilities in order to understand link from industrialization (signaled by agricultural land conversion) to human development. The framework is shown as the below chart.

Chart 1: Analytical framework based on livelihoods and capabilities

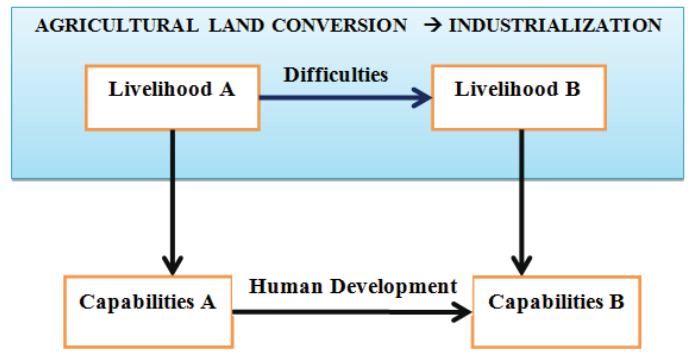

The framework assumes that, under context of agricultural land conversion, changes in livelihoods lead to changes of farmers' capabilities. This is important assumption although there is a dialectic relation between livelihoods and capabilities. According to this assumption, livelihood A generates capabilities A. Due to agricultural land conversion, livelihood $B$ replaces livelihood $A$, and correspondingly creates capabilities $B$. Hence, there is a shift from capabilities $A$ to capabilities B. This shift reflects the transition among livelihoods.

The framework takes the UNDP concept "human development" based on capabilities: Human development is the expansion of people's freedoms to live long, healthy and creative lives; to advance other goals they have reason to value; and to engage actively in shaping development equitably and sustainably on a shared planet. People are both the beneficiaries and drivers of human development, as individuals and in groups (UNDP, 2010: 22). Thus, the shift from capabilities A to capabilities B means change of freedom that farmers achieved, or a shift of human development of farmers.

\section{Methodology}

Primary data are gathered mainly through group discussion and in-depth interview. Secondary data and information are extracted from journal articles, books, and academic reports.

Group discussion is used with 20 people who had to convert their agricultural land for local industrialization in Hung Yen province. The group has 50\% males and 50\% females. In terms of age, participants are from 35 to 65 years old. The group discussion is used to understand difficulties emerged in livelihoods transition. Those participants had mentioned various aspects of livelihoods: income, working environment, working skills, size of production, market barriers, and so on.

In-depth interview has been implemented in Hai Phong province and Hung Yen province where had massive agricultural land conversion. In Hung Yen, the author interviews 10 households at Tan Quang commune, Vinh Khuc commune, and Luong Hoi Town. After land conversions, currently, they are doing agricultural production (animal husbandry), services (restaurants and rent house), and production (food processing, leather production). In Hai Phong, there are 10 interviewed households at Dang Cuong commune, An Duong district where has Nomura Industrial Zone and Dang Cuong Industrial Zone (schemed). In both provinces, interviewees are selected randomly among households that suffering strong impacts from land conversion. In-depth interview is used for examining how people are after land conversion.

Hai Phong and Hung Yen are two of the most rapid industrializing provinces in Vietnam since 1990s (Huong et al., 2012). Common characteristics of those provinces are high rate of agricultural land conversion, exceeding labours of farmers, booming of industries and manufacturing (Duong and Tha, 2012).

\section{Findings And Discussion}

\subsection{Agricultural land conversion for industrialization and challenges in livelihoods}


Under rapid process of industrialization in the provinces neighboring Hanoi Capital, massive areas of agricultural land have been transformed for industrial zones. In Van Lam district (Hung Yen province), near the border with Hanoi Capital, over 14000 households had lost almost 750 hectares of agricultural land for industrial zones in period $2000-2010$. The rate of land conversion was really high in many communes as Lac Hong commune ( $98 \%$ of agricultural land), Trung Trac (94.23\%), Tan Quang (62.17\%)...(Hanh et al., 2013). According to annual report from Department of Agriculture and Rural Development Hung Yen, just in year 2007, four rice-specialized fields at Phu Cu, Tien Le, Kim Dong, and Hung Yen town had to converted over 500 hectares for establishing industrial zones. Similar situations were also happened in other provinces nearby Hanoi as Bac Ninh, Vinh Phuc...(Luu and Phuc, 2008).

Industrialization has changed many aspects of rural areas. Both 20 group participants and 20 interviewees pointed that rural infrastructure improved rapidly with better traffic system, electricity, post offices, schools, and other buildings. However, rural environment also downgraded noticeably. In terms of living standard, income per capita went up during over 10 years of industrialization in rural areas. The most significant change is that farmers have to seek new livelihoods. National and local surveys indicate that people in rural areas select various working activities as handicraft, manufacturing, joining companies, running business, migration, construction, street vending (Dien, 2011, Hanh et al., 2013).

As a consequence, social stratification in rural areas is increasing quickly. The gap between the rich and the poor has been extended more widely. In-depth interview at Tan Quang commune, Vinh Khuc commune, and Luong Hoi Town (Hung Yen province) showed that richest households earned over 100 million VND (over USD5000) per year while the poor could get only below 10 million VND (around USD500). The rich are those ones took advantages from industrialization in rural areas: accumulating lands, opening farm, building guesthouse, running new business, working abroad. Gradually, they got higher income that allows them to buy cars, estates, new villas, and so on. In contrary, the poor are the ones having uncertain jobs, selling labour, or facing risks as health problems or accidents. Briefly, after land conversion, former homogeneous farmers group is divided into the rich, the middle farmers (who can afford only their own lives without saving), and the poor. Obviously, not all households having no agricultural land became the poor; however, many poor people in rural areas lack productive materials, especially agricultural land which was a direct consequence from agricultural land conversion for industrial zones in recent decades.

\subsection{Farmers' capabilities after agricultural land conversion}

Stiglitz, Sen and Fitoussi identify 9 basic capabilities: health, education, economic security, the balance of time, political voice and governance, social connection, environmental conditions, personal security, subjective measures of quality of life (Alkire, 2010: 34). This research stresses several specific aspects as economic security, social connection, and environmental conditions.

In the period of post-land conversion, household's economic security become very vulnerable. During transition between livelihoods, source of income from agricultural production was cut but new income is not set up stably. Those households having long transition (several months, or even 1-2 years) were affected negatively by quick decline of income. In addition, after land conversion, new livelihoods as running business, labouring in factories become more sensitive with market situation. Moreover, volatility of market and high competition lead household's economic security to be less stable.

Box 1: Economic competition in Vinh Khuc Commune, Hung Yen

"Competition in my field (leather manufacture) is so harsh. I cannot compete with big firms who produce at large volume and distribute to provinces through branches system. I cannot sell products at far provinces"1.

In-depth interview, Male, 68 years old in Vinh Khuc Commune, Hung Yen,

Economic environment worsens in recent years because of crises in early and late 2000s. In Hung Yen and Hai Phong, hundreds firms collapsed or stopped temporarily, especially small enterprises, which, in turn, demolish economic opportunities for households in rural areas. Due to such economic problems, workers who had been farmers before

\footnotetext{
1 "Cạnh tranh trong ngành của bác rất mạnh. Bác không thể cạnh tranh được với những công ty lớn. Các công ty này sản xuất ở quy mô lớn và có thể phân phối ở các tỉnh thông qua hệ thống chi nhánh. Bác không thể giao hàng tại các tỉnh xa"
} 
usually stood in the list of wage-cutting in factories, at the same, other farmers could not sell goods and services as good as before.

Social connection among households had changed significantly from relation based on relatives and neighbouring to relations focused on economic activities. Before land conversion, farmers had much free time for meeting, helping each other, visiting relatives. They also shared collective activities on fields so that they were harmony and honest. After land conversion, such connection reduced and replaced steps by steps by new connections for economic competitiveness. Doing new livelihoods, households have little time for meeting people, not as frequently as before. Besides, new social connections are mainly used for economic purposes.

\section{Box 2: Economic connection}

"Ornament tree Club is established for purpose of exchanging techniques and market information. The club helps us rising and looking after ornament trees, then sells at higher price"2.

In-depth interview, Male, 64 years old, at Chien Thang village, Dang Cuong Commune, Hai Phong,

Hence, social connections of people after land conversion had downgraded from multi-dimensions included helping, supporting, sharing each other to one dimension: cooperating for competition.

Environmental condition in rural areas worsens after land conversion. This is one of the most visible impacts from industrialization in rural areas. Owing to weak control of local authority, firm threw directly industrial wastes to water and land next to industrial zones. Processed wastes are limited because recycle system operated ineffectively or not used. By saving recycling cost, enterprises in rural areas earn much profit so they expand their production. In turn, this leads to more serious pollution in rural areas.

Box 3: Water and air pollution in village

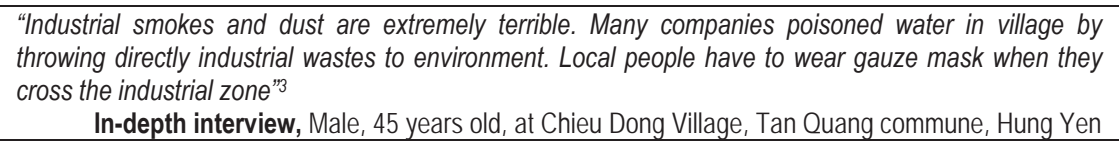

Meanwhile, converted land for industrialization usually locates near main roads and living places, thus, households are affected quickly and strongly from environment pollution made by enterprises.

Box 4: Noise pollution in village

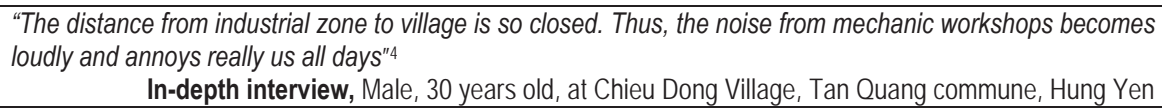

Briefly, rural people's basic capabilities as economic security, social connection, and environmental condition had been changed negatively after land conversion for industrialization. It implies that the transition during before and after land conversion contains much challenge that undermined basic capabilities of rural people. Determined by such capabilities, human development in rural areas faces a lot of constraints after land conversion.

\subsection{Difficulties in transition}

Firstly, households lack financial resources for running independently new livelihoods. Group discussed that after land conversion, they want to increase size of husbandry production as raising chicken or pigs. However, they cannot borrow

2 "Hội cây cảnh được lập ra để giúp trao đổi kỹ thuật và thông tin thị trường. Nhờ có hội này, chúng tôi trồng và chăm sóc cây cảnh tốt hơn, và nhờ đó bán được giá cao hơn"

3 "Khói và bụi từ khu công nghiệp rất khủng khiếp. Nhiều công ty đã xả trực tiếp chất thải công nghiệp vào môi trường. Người dân địa phương phải đeo khẩu trang mỗi khi đi qua khu công nghiệp"

${ }^{4}$ Khoảng cách từ khu công nghiệp đến làng lả rất gần. Do đó, tiếng ồn từ các xưởng cơ khí là rất to và gân khó chịu cho dân dư xung quanh suốt cả ngày" 
capital from bank and other credit institutions where always require complicated procedure of lending. Meanwhile, it is hard to borrow money from individuals as friends and relatives.

Box 5: Lack of financial resources

"It is very hard to borrow from banks because certificates of our land right have not issued. Besides, bank procedures for lending are complicated for us. Meanwhile, we cannot borrow from relatives and friends because they usually deposit their properties at bank in order to gain monthly returns" 5

Group discussion, Female, 50 years old, Tan Quang Commune, Hung Yen

Their own financial resource is really limited because income from previous agricultural production was low. After land conversion, households for compensation, however, it was too small in comparison with value of land. Furthermore, household usually divided compensation into many parts and gave to all members of households. Many group participants admitted that they used compensation for buying new furniture, building new houses. Hence, there was little money left after land conversion. Generally, financial resources from bank, credited institutions, individuals, and ownership are limited and hard to reach farmers who suffer land conversion.

Secondly, farmers lack new working skills for building new better livelihoods. Without land, farmers cannot practice previous farming skills. In steads, they have to be workers, servants, sellers or doing other livelihoods. For example, some group participants said that they cannot run a business at the market because they do not have business skills and confidence. Labour structure had changed to the trend that lowering in agricultural sector and increasing in nonagricultural sector. For example, in Van Lam district (Hung Yen province), rate of agricultural labour reduce from 79.98\% (2000) to $27.09 \%$ (2010), rate of non-agricultural labour increase from $20.02 \%$ (2000) to $72.91 \%$ (2010) (Hanh et al., 2013). Training class already opened for farmers in several livelihoods: flower and vegetable production, handicraft, garment, aquaculture... However, such training is ineffective so that farmers cannot apply new working skills for starting new livelihoods.

Thirdly, households lack market information and market linkages. New livelihoods require farmers to engage tightly to market by buying inputs and selling outputs. However, most of them live in rural areas and travel within short range from hometown. Hence, they know little about price of inputs and outputs, changes in market. As consequence, they cannot foresee next moves of market, and of competitors. In addition, farmers in rural areas have little market linkages with other players, especially those ones in urban areas. They keep exchanging with acquainted sellers and buyers. They are fixed in a small market where constraints them to be more dynamic and effective.

\section{Box 6: Shortage of market information and market linkage}

"We sell agricultural products mainly for middle men. Distance to retail markets is long, thus we do not know consumers' interest in order to adjust. Besides, we face limitedness of transportation to far markets. We only do small business in near markets"6

Group Discussion, Female, 35 years old,Chieu Dong village, Tan Quang Commune, Hung Yen

Fourthly, most farmers who had land conversion are middle age which is not suitable for new promising livelihoods. 18 of 20 group participants shared that they cannot apply jobs in companies due to constraints of age.

\footnotetext{
5 "Chúng tôi vay ngân hàng rất khó vì chưa được cấp giấy chứng nhận quyền sử dụng đất. Bên cạnh đó, thủ tục vay vốn của ngân hàng rất phức tạp đối với người dân. Trong khi ấy, chúng tôi không thể vay từ bạn bè và người thân vì họ thường gửi tiết kiệm tại ngân hàng để lấy lãi hàng tháng"

${ }^{6}$ Chúng tôi chủ yếu bán nông sản cho một số người mua buôn. Khoảng cách từ đây đến các chợ bán lẻ rất xa nên chúng tôi không biết được thị hiếu tiêu dùng của họ để điều chỉnh phù hợp. Bên cạnh đó, chúng tôi bị hạn chế về phương tiện di chuyển từ nơi sản xuất đến thị trường tiêu thụ. Chúng tôi chỉ có thể buôn bán nhỏ ở chợ gần đây.
} 


\section{Box 7: No job at middle age}

"Companies only hire workers from 20 to 35 years old. Thus, they do not welcome over-40 years old men like us. At my age, 46, I cannot apply any job in company. Therefore, I have to run a small shop at home and sell my labour sometimes"7

Group Discussion, Male, 46 years old, Chieu Dong village, Tan Quang Commune, Hung Yen

At age of over 35, labourers have less encouragement for studying and training. Hence, when new livelihoods require new working skills, such over-35 labourers cannot meet those requirements. Thus, over-35 farmers find difficultly jobs in companies. Besides, since middle age farmers became less active, less dynamic, and less creative, they fear failures and do not dare to change. Those are main barriers that preventing them to start good livelihoods. Alternatively, farmers at middle age sell their labour at construction sites, caring children. Few become venders while some others open small shops at home.

\section{Conclusion}

The research has showed that agricultural land conversion for industrialization affects strongly to livelihoods of farmers in Hung Yen and Hai Phong provinces. Under this context, farmers adapt with new livelihoods which vary from working at companies, selling goods at market, running small shop at home, to doing services (restaurant, guest house...), and so on.

Social stratification happens among farmers who lost agricultural land. The farmers group is divided into the rich, the middle farmers (who can afford only their own lives without saving), and the poor. In which, the rich takes much advantages form industrialization while the poor suffers uncertainty of jobs and other risks.

Changes in livelihoods make a shift of capabilities of farmers. Generally, those ones having high ratio of land conversion downgrade their basic capabilities in economic security, social connections, and environmental conditions. Therefore, this denotes that human development in rural areas faces a lot of constraints after land conversion.

Problem in human development and social stratification imply difficulties in transition among livelihoods under impacts of agricultural land conversion. There are several main difficulties of farmers and household at rural areas: lack of financial resources, new working skills, market information, market linkages, and constraint of age.

\section{References}

Alkire, S. 2010. Human Development: Definitions, Critiques, and Related Concepts. United Nations Development Programme (UNDP).

Anh, D. N. 2007. Policies of resettlement for hydropower projects in Vietnam: From angle of social studies. Journal of Population and Development, Volume 6/2007.

Bui, T. M. H. \& Schreinemachers, P. 2011. Resettling farm households in northwestern Vietnam: livelihood change and adaptation. International Journal of Water Resources Development, 27, 769-785.

Bui, T. M. H., Schreinemachers, P. \& Berger, T. 2013. Hydropower development in Vietnam: Involuntary resettlement and factors enabling rehabilitation. Land Use Policy, 31, 536-544.

Bury, J. 2004. Livelihoods in transition: transnational gold mining operations and local change in Cajamarca, Peru. The Geographical Journal, 170, 78-91.

Chambers, R. 1983. Rural development: Putting the last first. Longman Scientific Technology.

Chambers, R. 1987. Sustainable Rural Livelihoods: A Strategy for People, Environment, and Development, Institute of Development Studies at the University of Sussex.

Chambers, R. 1995. Poverty and livelihoods: whose reality counts? Environment and Urbanization, 7, 173-204.

Chambers, R. \& Conway, G. 1992. Sustainable rural livelihoods: Practical concepts for the 21st century, Institute of Development Studies (UK).

Dien, N. T. 2011. Land conversion for industrialization and its impacts on household livelihood strategies in Hung Yen province, Northern Vietnam. PhD Thesis, University of Liege, Gembloux Agro-Bio-Tech.

Dung, L. C., Thanh, D. N. \& Sanh, N. V. 2008. Impacts of urbanization on livelihoods: Case study in Long Tuyen ward, Can Tho City. In: XUAN, V. T. (ed.) Sustainable rural development - Land policies and livelihoods: Working papers 2004 - 2007. Hanoi: Agricultural Publishing House.

Duong, P. H. \& Tha, T. H. 2012. Environmentally Sustainable Development in the Northern focal Economic Region of Vietnam.

${ }^{7}$ Các công ty chỉ thuê công nhân từ 20 đến 35 tuổi. Do đó, họ không thuê những người trên 40 tuổi như tôi. Ở tuổi 46, tôi không thể tìm được việc làm tại công ty. Và thế, tôi phải mở một cửa hàng nhỏ tại nhà và thỉnh thoảng làm thuê kiếm tiền. 
Ellis, F. 2000. Rural livelihoods and diversity in developing countries, Oxford University Press.

Fukuda-Parr, S. 2003. The Human Development paradigm: Operationalizing Sen's ideas on capabilities. Feminist Economics, 9, 301317.

Ha, T. V., Phu, P. X., Tri, N. H. \& Thanh, V. D. 2013. The impact of hydro-power dams on sustainable livelihood development of lower basin area inhabitants, Hanoi, Educational Publishing House.

Ha, T. V. \& Tranh, D. 2011. Research on resettlement in hydropower projects in the Doi Moi period, Hanoi, Encyclopaedia Publishing House.

Hanh, N. T. H., Tra, N. T. \& Tra, H. T. L. 2013. Impscts of agricultural land conversion to life, the jobs of farmers in Van Lam District, Hung Yen Province. Journal of Science and Development, Volume 11 - No 1.

Huong, V. T., Long, P. \& Lan, P. 2012. Strategies to Promote Sustainable Development of Industrial Parks in Vietnam's Northern Key Economic Zone. Journal of Modern Accounting and Auditing, 8, 145-151.

Long, N. 1984. Family and work in rural societies: perspectives on non-wage labour.

Luu, T. \& Phuc, V. 2008. Agricultural land and farmers in rural urbanization - Part 1: Fields transformed to industriali zones [Online]. Available: http://www.sggp.org.vn/phongsudieutra/2008/4/149911/ [Accessed 8 July 2013].

Scoones, I. 2009. Livelihoods perspectives and rural development. The Journal of Peasant Studies, 36, 171-196.

Swaminathan, M. S. 1987. Food 2000: Global policicies for sustainable agriculture, report to the World Commission on Environment and Development, London, Zed Press.

Trouw, J. 2007. The Three Gorges Dam's impact on peasant livelihood China's project on the Yangtze River, Norderstedt, Books on Demand.

Tuan, V. V., Dung, L. C., Thanh, D. N., Sanh, N. V. \& AL., A. E. 2008. Livelihoods of landless rural households in the down stream flooding area in the Mekong Delta. In: XUAN, V. T. (ed.) Sustainable rural development - Land policies and livelihoods: Working papers 2004 - 2007. Hanoi: Agricultural Publishing House.

UNDP 2010. Human Development Report 2010: The Real Wealth of Nations: Pathways to Human Development, New York, Palgrave Macmillan.

Wilmsen, B., Webber, M. \& Duan, Y. 2011. Involuntary Rural Resettlement: Resources, Strategies, and Outcomes at the Three Gorges Dam, China. The Journal of Environment \& Development, 20, 355-380. 